\title{
A Comparison of the Metadata Used in Some European Archives with Special Reference to Ottoman Records
}

\author{
By Elif Yllmaz Şentürk*
}

\begin{abstract}
Ottoman records are distinct from contemporary records both in terms of diplomatic characteristics and content. It is for this reason that Ottoman records should not be described by metadata elements developed for contemporary records. In addition, no publications or standards aimed at the description of Ottoman documents have been encountered. This study has researched which metadata are used to describe Ottoman records found in collections in Turkey and Europe.
\end{abstract}

Keywords: Description, Diplomatica, Metadata, Ottoman Records.

\section{Introduction}

Metadata, which in the archival world is a description exercise defined as "data about data," should present the researcher with both the intellectual content and form characteristics in a correct and complete manner. Ottoman documents are distinct from contemporary records both in terms of diplomatic characteristics and intellectual content. Thus, it is for this reason that Ottoman documents need to be described using different metadata elements.

The format characteristics of documents that are interpreted to be "diplomatic" provide a plenitude of contextual information, such as the sender/ respondent title and period of composition. Diplomatic characteristics, such as the signature on the document and the type of paper used, provide clues to the researcher regarding the intellectual context of the document even if the document contains no script. Thus, the description of Ottoman documents should be undertaken without omitting any contextual or diplomatic characteristics by information and records managers who have an expertise in diplomatics.

Diplomatics can be defined as the study of the creation, forms, and transmission of records, and their relationship to the facts represented in them and to their creator, in order to identify, evaluate, and communicate their nature and authenticity (Pearce-Moses 2005: 120). The mode of use, conditions and the location of use of Ottoman documents are the elements of which the science of diplomatics comprises (Kütükoğlu 2013: 4). Diplomatics is the discipline that examines the characteristics of records, (Kütükoğlu 1994: 364) and is one of the auxiliary sciences of history (Gökbilgin 1992: 13). External appearance carries great importance when examining the diplomatics of records. Type, type of script, use of leaf, symbols on leaf (seal or signature of a sultan, abbreviated signature or "claw", "tailed signature" etc.), paper used,

${ }^{*}$ Research Assistant, Marmara University, Turkey. 
gliding and ink are examples of characteristics that should be considered when examining the diplomatics of documents. Annotations that appear on the back cover of a document are just as important as the annotations found on the front cover of a document. In fact, a small symbol or the manner in which it is written, apparent from a superficial examination, may be of upmost importance (Kütükoğlu 2013: 13). It is impossible to evaluate documents without knowing the meaning implied by script in documents even if the language used by society is known and can be read. Topics such as the dating of undated documents and distinguishing forged documents from authentic ones all fall within the scope of the science of diplomatics (Kütükoğlu 1998: 12-13).

Throughout this study, the Thesis Centre database of Turkey's Council of Higher Education was examined. A survey of the abovementioned database revealed that between 1999-2017 six Doctorate and seven Masters Theses were written containing the heading of "metadata". Whereas an examination of theses written abroad on the subjects of "library science, information science, information technologies" and containing the heading of "metadata" found in the database called "ProQuest Dissertations and Theses Global" revealed fiftytwo theses. However, of all the theses located none were written on the topic of Ottoman documents. This study aims to remedy the shortage in the literature of the field with regard to Ottoman documents.

\section{The Primary Turkish Archives who hold Ottoman Records}

\section{The Ottoman Archives of the Prime Ministry}

Founded in 1846, the national archive of the Ottoman State, Hazine- $i$ Evrak, continued its archival mission after joining the Republic of Turkey Prime Ministry to formas the "Ottoman Archives of the Prime Ministry" after the proclamation of the Republic. The metadata identified using the database of the Ottoman Archives of the Prime Ministry are mentioned in Table 1.

Table 1. Metadata Used in the Database of the Ottoman Archives of the Prime Ministry

\begin{tabular}{|l|}
\hline Metadata \\
\hline Fond Name \\
\hline Fond Code \\
\hline FileCode \\
\hline Sleeve No \\
\hline Islamic Date \\
\hline Subject \\
\hline Record Piece(s) \\
\hline
\end{tabular}

The Ottoman Archives Manual published in 1992 stated under the heading of "procedures required to ensure archival material is accessible to the researcher following transfer to the archives" that the necessary principles and procedures for classification to be implemented at the archives had been stated 
(Binark 1992: 6). A slip is prepared on which the documents are summarised. These slips contain the answers to questions relating to document content, such as who, where, why and when.

Table 2. The Ottoman Archives Summary Slip

\begin{tabular}{|l|l|}
\hline Code: & File No: \\
\hline Date: & Sleeve No: \\
\hline Parts: & Microfilm No: \\
\hline SUMMARY \\
\hline \\
\hline SUBJECT: \\
\hline \multicolumn{2}{|c|}{ INDEX } \\
\hline Name of Individual: \\
\hline \multicolumn{2}{|c|}{} \\
\hline Place Name: \\
\hline Organisation and Terminology: \\
\hline \multicolumn{2}{|c|}{}
\end{tabular}

Source: Binark 1992: 9.

The metadata found on the summary slip of the Classification Guidelines is not captured within the database of the archive's database. The incorporation of the index fields of the summary slip into the database currently used would ensure that information is accessed more swiftly and in the correct fashion.

\section{Archives of the Ministry of Foreign Affairs}

The organisation of the Reisülküttabllk, which was responsible for foreign affairs, transferred to the Hariciye Nezareti (Ministry for Foreign Affairs) in 1836 (Findley 1997: 179). The first charter relating to organisational structure was published in 1835, following the conversion of the Reisülküttablık to the Hariciye Nezareti. The Hariciye Nezareti was subsequently abolished in 1922 following the establishment of the Turkish Grand National Assembly (Girgin 2004: 74). Following the establishment of the National Assembly and the promulgation of the law "Büyük Millet Meclisi İcra Vekillerinin Suret-i İtihabına Dair Kanun" (Law Regarding Election of Grand National Assembly Cabinet Ministers) ( $3^{\text {rd }}$ Law, 1921), the Hariciye Vekaleti (Foreign Office) officially came into existence (Girgin 2004: 212).

The archives of the Ministry for Foreign Affairs consist of archival material generated by central and foreign-based organisational units, following the undertaking of a specific procedure. Files are saved by the creating departmental unit. The archives hold the following types of archival material: written documents in both physical and digital formats, registers, illustrations, plans, maps, projects, seals, stamps, photographs, film, audio and visual tapes, discs and similar material. 
The metadata used for Ottoman records in the Foreign Affairs Diplomatic Archives Directorate database (DIAD) are as follows:

Table 3. DIAD Metadata used in Database

\begin{tabular}{|l|}
\hline Metadata \\
\hline Document Type \\
\hline Date \\
\hline Approximate Date \\
\hline Document Number \\
\hline Language \\
\hline Level of Classification \\
\hline Printed Document \\
\hline Handwritten \\
\hline Fond Name \\
\hline Relevant Date \\
\hline Relevant Number \\
\hline Provenance \\
\hline Receiving Organisation \\
\hline Tag \\
\hline Description \\
\hline Requires Restoration \\
\hline Document Appendix not Accessible \\
\hline Date Critical Document \\
\hline Summary/Subject \\
\hline
\end{tabular}

Source: Kandur, Yalçınkaya and Yılmaz 2016: 9-10.

\section{Collections of Ottoman Records Found in Some European Archives and Libraries}

A sizeable proportion of records found in European archives are written in Ottoman Turkish script. This is because the Ottoman State consistently pursued diplomatic relations with European states and as a result correspondence ensued (Köksal and Polatel 2014: 6).

The Ottoman Empire was also an instrumental actor in shaping the European political landscape into its current form. The Ottoman Empire played a significant role in shaping European history from the mid- $15^{\text {th }}$ century onwards (İnalc1k 2017: 7). For example, Holland, when it emerged as a state, first embarked on diplomatic relations with the Ottomans, and in the $18^{\text {th }}$ century it was the Ottoman Empire that was the first state to oppose the dissolution of Poland (İnalcik 2014: 171).

Within the scope of this study, the archives and libraries of some of the organisations of Bulgaria, Greece, Italy, France and the United Kingdom were examined. For the purposes of this study, with the exception of the Ottoman Archives of the Prime Ministry, databases with open access to researchers were utilised. The metadata used in the description of Ottoman records were translated to English and similarities with each other were sought. 


\section{Ottoman Records Found in Bulgaria}

\section{$\underline{\text { Bulgarian Cyril and Methodius Library }}$}

Some documents belonging to the Istanbul Revenue Office Archives (İstanbul Defterdarlığı Maliye Arşivi), which relate to Ottoman military, financial, commercial, political, legal, literary, industrial, maritime and science history, were sold to Bulgaria in 1931. These documents were sent (Aktaş and Kahraman 1994: xiv; Torunlar and Çelik 1993: xix) to a paper factory in Bulgaria to be converted to high-grade paper pulp and can be found today in the Cyril and Methodius Library, which is the Bulgarian national library (Aktaş and Kahraman 1994: xix). On its website the Cyril and Methodius Library classifies its Ottoman records under three headings: Eastern Records/Europe, Eastern Records/Bulgaria and the Balkans, and Eastern Records/ Arab nations and Iran.

It can be seen from an examination of the metadata used by the Cyril and Methodius libraryfor describing their Ottoman records that the libraries, compared to other organisations that also hold Ottoman records, undertake a more detailed description of records. As an example, the Cyril and Methodius library uses metadata to describe the diplomatic characteristics of Ottoman records that even the Ottoman Archives of the Prime Ministry does not use. For example, it is apparent that the Cyril and Methodius library uses metadata relating to the diplomatic characteristics of records such as "record type", "script type", and "ink", in addition to metadata that reveals the administrative processes involved in the production of records such as "place of production", "originating organisation", and "creator/owner" (Database of Ottoman Documents in Crill i Methodius Library n.d.)

Table 4. Metadata Used for Ottoman Records in the Cyril and Methodius Library

\begin{tabular}{|l|l|}
\hline Metadata & Equivalent in English \\
\hline Сигнатура & Reference Code \\
\hline Език & Language \\
\hline Дата АН / AD & Date (Islamic and Gregorian) \\
\hline Наименование & Document Type \\
\hline Адресант & Addresses \\
\hline Институция / адресант & Originating Organisation \\
\hline -местоиздаване & Place of Production \\
\hline Адресат & Addresses \\
\hline Институция / адресат & Receiving Organisation \\
\hline -местополучаване & Recipient \\
\hline Тематика & Subject \\
\hline Анотация & Note \\
\hline Размер & Size \\
\hline Писмо & Letterform \\
\hline Мастило & Ink \\
\hline Публикации & Publication \\
\hline Описал / дата & Date of Description \\
\hline Доп.информация & Additional Information \\
\hline
\end{tabular}


Vol. 3, No. $4 \quad$ Senturk: A Comparison of the Metadata Used in Some European...

\section{Ottoman Records found in Greece}

\section{Greek National Archives}

Under the auspices of the Greek National Archives, the database A $\chi \varepsilon เ о \mu \nu \eta \dot{\mu} \omega \nu$ (Arheiomnimon) renders it possible to access online 37 different regional archival collections ${ }^{1}$ (Greek State Archives). With the aim of ensuring international access, the archival collections have been translated into English and an international standard, International Standard of Archival Description (General) (ISAD $(G))$, is used in the description of records. Arrangement of the archives is carried out on the basis of region. Series are thus named according to region; thoseat the Greek National Archives containing Ottoman records include the Archives of Imathia, Archives of Kozani, and Historical Archives.

\section{$\underline{\text { Kaireios Library of the Island of Andros }}$}

The database of the Kaireios Library on the Island of Andros provides access to short summaries, transliterations and transcriptions available online of Ottoman documents held in Kaireios Library, Hagia Monastery and Hagios Nikolaos dating from 1579-1821. The transliteration of submissions, petitions, applications, letters, the Sultanic Cipher on documents, memorandums, deeds, inheritance registers, fetwas, decrees and title-deeds was undertaken by Assoc. Prof. Dr. Elias Kolovos from the Department of History \& Archaeology at the University of Crete. The database was developed by Yorgos Vidras and Aris Kydonakis ${ }^{2}$ (Andros Island Library).

The database that provides direct access to Ottoman records for researchers provides the record number, type and date. Due to the fact that a full text search is possible using the database, it is possible to search using any Turkish word that appears in the text.

Table 5. Metadata Used in the Database of the Kaireios Library

\section{Metadata}

Document Type

Date (Islamic Calendar)

Date (OS)

Summary

Source

Any word or phrase

No. (id\#)

\footnotetext{
${ }^{1}$ http://arxeiomnimon.gak.gr/index.html

${ }^{2}$ http://androsdocs.ims.forth.gr/
} 


\section{Ottoman Records Found in Italy}

\section{$\underline{\text { State Archives of Venice }}$}

The State Archives of Venice (Archivio di Stato di Venezia) contain significant evidence of the commercial, political and cultural links between Byzantine Constantinople and Venice. In addition, the archives contain a huge number of records about the Ottoman Empire, the quantity of which is hard to estimate. The collections also comprise some Ottoman court records belonging to private individuals. With the exception of archives found in former Ottoman territories, it can be stated that the State Archives of Venice holds the most Ottoman records. Ottoman records in the Venetian archives are held in three different series. These are the series of "Documenti turchi", "Leterre e scritture turchesche" and "Balio in Cosnstantinopoli" (Pedani 2010: ix). The State Archives of Venice holds 4000 records relating to the Ottoman Sultans, 300 of which date from the second half of the $15^{\text {th }}$ century (Reychman and Zajaczkowski 1993: 40).

One of the most important Ottoman collections of the State Archives of Venice has been made accessible online. The abovenamed archive is one of the most significant archives in terms of archival material pertaining to Ottoman history. A large proportion of the archival material relating to the Ottoman Empire is accessible under the auspices of Progetto Divenire from the Venetian website. The Ottoman records found in the Miscellanea Documenti Turchi collection have undergone digitalisation and are accessible online to the researcher.

In the 1980s, Maria Pia Pedani embarked upon the classification and catalogue creation of the above collection which resulted in the publication of the "Documenti turchi dell Archivio di Stato di Venezi" catalogue in 1994 (Pedani 1994). In 2006, the National Research Council in Florence (Consiglio nazionale delle ricerche di Firenze) and the Venetian Archives began the digitalisation process of this collection in partnership with Progetto Divenire (Venetian State Archives Online).

The Ottoman records collection containes 2,022 chronologically arranged records, relating to Ottoman-Venetian relations between the $15^{\text {th }}-19^{\text {th }}$ centuries. The documents No.1-1997 contain material dating from 859/1454 to 1252/1837. A large proportion of the collection's records (no.1118-1609) date from the $17^{\text {th }}$ century, whilst a sizeable number of records (no.73-1117) date from the $16^{\text {th }}$ century. The variety of record types ranges from painstakingly created official records, such as Imperial Council Orders and treaties, to short letters and reports written by Ottoman provincial officials in the Balkans. Even though the majority of records in the collection are in Ottoman Turkish, records in Greek, Italian and Arabic can also be found. Many records have an Italian summary and some have been translated into Italian. Some documents found within this collection that are written in Greek and bear the Sultan's Cipher (tughra) are particularly noteworthy (Miscellanea documenti turchi 2017).

The metadata used for the records in the collection of Miscellanea documenti turchi when captured in the database are shown in the table below. The metadata and comprising information is written in Italian. The most 
noteworthy of the metadata elements used is "DA," which has the meaning of Reference. Here, a reference to the Venetian Ottoman records Catalogue published in 1994 by Maria Pia Pedani is given.

Table 6. Metadata Used in the Description of "Miscellanea Documenti Turchi"

\begin{tabular}{|c|c|c|c|}
\hline \multicolumn{2}{|c|}{ Metadata } & \multicolumn{2}{|c|}{ Equivalent in English } \\
\hline Identificazione & Numero documento & Reference Number & Document Number \\
\hline \multirow{2}{*}{ Datazione } & Data iniziale & \multirow{2}{*}{ Dating } & Firstdate \\
\hline & Data topica & & Thematic Date \\
\hline \multicolumn{2}{|c|}{ Mittente } & \multicolumn{2}{|c|}{ Originator } \\
\hline \multirow[t]{2}{*}{ Destinatario } & Destinatario & \multirow[t]{2}{*}{ Recipient } & Recipient \\
\hline & Qualifica & & Attributes \\
\hline \multicolumn{2}{|c|}{ Descrizione } & \multicolumn{2}{|c|}{ Description } \\
\hline \multirow[t]{2}{*}{ Dimensioni } & Base mm & \multirow[t]{2}{*}{ Measurements } & Length $\mathrm{mm}$ \\
\hline & Altezza mm & & Height mm \\
\hline \multicolumn{2}{|c|}{ Lingua } & \multicolumn{2}{|c|}{ Language } \\
\hline \multicolumn{2}{|c|}{ Tradizione } & \multicolumn{2}{|c|}{ Status } \\
\hline \multicolumn{2}{|r|}{ Da. } & \multicolumn{2}{|c|}{ Source } \\
\hline
\end{tabular}

\section{Ottoman Records Found in France}

France is one of the countries that especially comprehends the importance of archival services, gives special attention to archival matters, and acts early on such issues (Erdoğdu 2014: 67). In France many private and public archives hold records from the Ottoman period. These are primarily the French Archives (Les Archives Nationales) and the French Ministry of Foreign Affairs Archives (Archives du Ministère des Affaires Étrangère), followed by the French Armed Forces Archives (Les Arhives du Château de Vincennes), which holds the records of the Ministry of Defence and Gendarmerie, and the archives of Les Archives de la Chambre du Commerce et d'Industrie de Marseille-Provence in Marseille, which contains records of those who migrated to France during the Ottoman period.

Ottoman documents can also be found in the Gallica collection in the digital library of the French National Library (Bibliothèque Nationale de France) and its stakeholders. The 25 decrees signed by the Sultan Mahmud I and sent from Istanbul in $1161 \mathrm{H}$. is one of the most important records of this collection (Gallica 2017). Despite these decrees being written in Ottoman Turkish script, they have been described as Arabic.

The metadata used in the description of the Ottoman documents in Gallica appears in the table below. 
Table 7. Metadata Used in the Description of Ottoman Records in Gallica

\begin{tabular}{|l|c|}
\hline Metadata & Equivalent in English \\
\hline Titre & Title \\
\hline Date d'édition & Date \\
\hline Type & Document Type \\
\hline Langue & Language \\
\hline Format & Format \\
\hline Description & Description \\
\hline Description II & Description II \\
\hline Droits & Rights \\
\hline Identifiant & Reference Number \\
\hline Source & Source \\
\hline Provenance & Provenance \\
\hline Date de mise en ligne & Date Open to Access \\
\hline
\end{tabular}

\section{Ottoman Records Found in the United Kingdom}

The primary material to be found at the National Archives relates to British history. The preservation of records relating to other countries however is changeable and depends on the extent of the relationship between the United Kingdom and the country in question. Due to the fact that diplomatic relations between Turkey and England started in 1580, records relating to the Ottomans are only available from this period onwards (Kurat 1949: 2).

For the purposes of research on Ottoman and Turkish history, the most comprehensive data found at the National Archives is that containing the Foreign Office records. This find comprises of the reports and correspondence written by English diplomats posted in Turkey. In addition, records from an earlier period relating to the Levant Company on English-Ottoman relations can be found in the "State Papers" (SP) fond. Records preserved at the National Archives on this topic can also be found in the War Office (WO) and Admiralty (ADM) records. These finds contain important records from the perspective of $19^{\text {th }}$ century Turkish history (Ünver 2014: 114-115).

Upon searching the word "Ottoman" in the National Archives search engine Discovery (Discovery 2017), 17,659 catalogue entries are generated. An examination of 2000 of these catalogue entries reveals that 1574 entries do not state the language of the document. In addition, Ottoman Turkish/Turkish is not the language stated for the catalogue entries of the documents that have language stated.

Due to the fact that a large proportion of these fonds have not undergone digitalisation, it is not possible to ascertain which records are written in Ottoman Turkish without visiting and examining the physical records at the National Archives in Kew in person. Despite this, the metadata used in the description of records relating to the Ottoman Empire can provide an insight into the records of the Ottoman Empire and are provided in the table below. 
Table 8. Metadata used in Discovery to Describe Ottoman Record ${ }^{3}$

\begin{tabular}{|l|}
\hline Metadata \\
\hline Reference \\
\hline Title \\
\hline Description \\
\hline Date \\
\hline Related Material \\
\hline Held by \\
\hline Legal Status \\
\hline Language \\
\hline Physical Description \\
\hline Access conditions \\
\hline
\end{tabular}

\section{Conclusion and Recommendations}

Throughout this study, the metadata elements used in databases by national and international archives and libraries, which have Ottoman records in their collections, were identified. This study probed whether the metadata elements used reflected to the fullest extent the diplomatic and intellectual context of the Ottoman records in the above collections. A survey of the databases of international archives and libraries in Europe revealed that only the Bulgarian Cyril and Methodius Library and the Greek Kaireios Library of the Island of Andros used metadata that described the diplomatic characteristics of Ottoman documents. Archives in Turkey, however, do not use any metadata to describe the diplomatic characteristics of Ottoman records, and the use of the necessary metadata of a standard that would ease the accessibility of the document and its content was not witnessed.

Access to Ottoman records is rendered difficult or in some cases almost impossible if metadata that do not completely reveal the diplomatic and intellectual content of the records, resulting in insufficient or lacking description, is used. This is especially the case in Turkey where historians use such terms as to "search for a record" and to "find a record". Archives are insufficiently described, resulting in classification not being carried out in accordance with well-accepted conventions. The correct classification and description will result in the shortening of the time a researcher spends on "searching for a document"; and ensures that the researcher comes across a record as a result of an informed search rather than as a "coincidence." The aim of this study is to ensure that the researcher accesses the information and records they are seeking in an expeditious and correct manner.

This study has highlighted that the metadata elements used in areas other than databases for collections of Ottoman records in both Turkey and Europe are inadequate and that they are a long way off from reflecting the diplomatic characteristics of the records. This predicament arises from the fact that

\footnotetext{
${ }^{3}$ FO 78, which is included in the Ministry of Foreign Affairs (Foreing Office) fund, includes documents with Turkey. When administrators were identified, the records contained in this sub-fund were examined. (Discovery 2017).
} 
historical records are distinct from modern and electronic records in terms of format and intellectual content.

The metadata that should be used for describing the diplomatic characteristics of Ottoman records are as follows:

\section{Record Type}

Each record type possesses its own characteristics and sometimes it is possible to ascertain the group of record type without having to read the entire text (Kütükoğlu 1998: 12-13). When assessing Ottoman records from any perspective, the record subject, function, creator or change in respondent should be divided into sub-divisions.

\section{Paper Type}

The kind and size of paper found in Ottoman documents depends on the type of record. Despite this, the paper used for the same type of document shows variation over time. The paper used for $16^{\text {th }}$ century decrees gradually increased in volume to the extent that large sized paper began to be used in the $18^{\text {th }}$ century for decrees. The same observation can be made for patents. Furthermore, there has always been a close correlation between the type of patent and their size. An examination of the size of Grand Vezierial Memoranda to Sultans reveals a striking reduction in size from the middle of the $18^{\text {th }}$ century to the end of the $18^{\text {th }}$ century. The types of paper most used in the bureaucracy of the Ottoman State were Istanbul, battal (large-sized) and telhislik (Grand Vezierial memoranda) (Kütükoğlu 2013: 30). Of the three types of paper it was the Istanbul paper that was used most widely. Decrees and secondary patents were also written on this type of paper. However, "Grand Vezierial memoranda paper" (telhis kă̆ldl) was preferred for Grand Vezierial Memoranda. Varying qualities of manilla paper was used for Sultanic Letters to other rulers (Name-i Hümâyûn), Treaty Letters (Ahidname-i Hümâyûn), menşur (appointments made by the Sultan) and mülknames (a Sultan's grant of ownership of public assets) granted to notables and for all patents and charters (Kütükoğlu 1994: 366).

\section{Writing Styles}

The design or style of fonts such as Gothic, Roman and Italic can be defined as font styles (Carter and Levin-Clark 2013: 259). Knowing a language in order to be able to use and research the records of a historical topic is one of the important points to bear in mind. However, knowledge of a language cannot be said to be sufficient with respect to historical research. A variety of writing styles such as nesih, sülüs, dîvânî, rik'a, ta 'lik and siyakat exist in the Arabic script. The usage of each of these respective writing styles is distinct. It is not possible to undertake research of a serious nature without learning to read the necessary writing styles. The identification of these styles and the 
branch of science concerned with their characteristics is called palaeography (Kütükoğlu 1998: 12). Palaeography in short is "the study and analysis of ancient writing, including the identification of origin, period, and the formation of individual characters" (Pearce-Moses 2005: 284).

The writing styles of Ottoman records are closely related to the record type. Decrees, sebeb-i tahrir hükmü (Orders issued by the Treasury), and some patents were written in the divanî ordivanî kırması (a more simplified version of divanî); whereas the celî- divanî style was preferred more for patents, letters and Imperial Treaties bestowed upon notable individuals. Buyruldu (Orders) were always composed in divanî or iri divanî and telhis (Grand Vezierial memoranda) were composed in the specific calligraphic style of harekesiz naskh style. Records composed for the purpose of Ifta (Act of issuing a legal opinion) and by a kaza (administrative division) and related bodies such as the Şeyhülislamlık (Office of the Shaykh al-Islam), kazaskerlik (Office of Chief Judge) and kadılık (Office of the Magistrate) were always written in the ta 'lik style. Two types of writing style were generally used for records of the Treasury. Ahkam (Judgement records) were written in divanî and accountancy records were written in siyakat style. Cadastral Registers were also written in siyakat style with the use of partial dots. The standard calligraphic style of the $19^{\text {th }}$ century was rik' $a$, but more commonly rik'a kirması (a more simplified version of rik'a) was used. Arz tezkireleri (reports on petitions), irade (decrees), and correspondence between state departments were always penned in the rik'a style (Kütükoğlu 1994: 366).

In order for documents that are not originally dated to be evaluated, the development and change of the calligraphic style used over the centuries needs to be considered. For instance, the writing styles of $15^{\text {th }}$ century cadastral registers do not remain static over following centuries, in the same way the style of registers of important matters of state in the $16^{\text {th }}$ century changes over later centuries. Over time, the annotations of records such as petitions underwent change both in terms of font characters in bureaus and writing style. An evaluation of Ottoman records, and dating, from a diplomatic perspective also requires knowledge of a palaeographic nature (Kütükoğlu 2007: 152). This means that in addition to the format characteristics of records, the different types of writing style should also be known.

Ink

Black ink was used for the purposes of daily correspondence in the Ottoman State (Derman 2006: 47). The use of red ink has also been seen in the annotations on some documents and registers. On some Patents, Sultanic Letters to other rulers, and Imperial Treaties the use of navy, green and gold coloured ink in addition to red was observed (Kütükoğlu 2013: 43).

However, there are very few experts, who would be able to describe the diplomatic characteristics of historical records, such as type of ink used and the type of paper the record was composed on today. 


\section{Unique Symbols}

The metadata element "unique symbols" is used to describe the affixing, application, sealing, writing, engraving or attachment of physical symbols, letters and abbreviationsto a piece of the document, or whole document, texts or dockets (with the exception of signs that are naturally present within watermarks) (Baca and Harpring 2014: 18). As with electronic records, signs such as letterheads, watermarks, seals, signatures and abbreviated signatures can also be found on Ottoman records (Kandur 2006: 97). These signs which are generally used for the purpose of certifying and verifying Ottoman documents are generally described under the metadata element of "Unique symbols on document". There is rhyme, reason and logicto every sign or symbol that appears on Ottoman records. Such signs need to be transcribed in order for the work on the record and its provenance to be determined.

In order to establish a link between the above metadata element and sub elements, international standards were examined. It was found that only in the standardTS 13298 can the following comparison can be made based on theseterms; "electronic signature" is the equivalent sub element to "signature" and the equivalent to the sub element "seal" is the "electronic seal". The sub elements of "electronic signature" and "electronic seal" despite not being identical to the "signature" and "seal" in the Ottoman period, nonetheless share the same characteristics in terms of certifying documents.

\section{Unique Symbols - Sultanic Cipher}

The majority of Sultanic Letters and all of the patents and decrees issued by the Sultan in the Ottoman State bear the Sultanic cipher (tuğra) (Kütükoğlu 2013: 99, 148). The Sultanic cipher used for official papers is chosen by the Sultan on the day of his accession from a number of samples and the text and composition of the cipher does not change until the end of the Sultan's reign, regardless of who the Sultan is (Acar 1999: 168). At first the tuğra was used on official papers such as decrees, patents and pious foundation papers but usage became more widespread over time resulting in stamps, coinage, other stamps and inscriptions bearing it (Turgut 2009: 81).

\section{Unique Symbols - "Claw"}

In the Ottoman State, the Grand Vizier, the vizier in the provinces and other high ranking officials such as the Beylerbeyi (Governor) and Sancakbey (Banner Commander) used an abbreviated signature ("claw") instead of a seal on their papers relating to state and province affairs through the powers granted to them. It is probably due to the shape of the sign that it was given the name "claw". The first 'claw' was encountered in the mid- $15^{\text {th }}$ century. The "claw" depending on the prominence of the notable in question was either used on the right-hand corner of the document or in the centre and was used instead of a signature reaching to the end of the document. 


\section{Unique Symbols - 'Tailed Signature'}

The signature used in the Ottoman State by senior provincial treasury officials on some documents prepared in financial administration was one that stretched downwards with the addition of a line and was called a "tailed signature" (Kütükoğlu 2013: 79).

\section{Unique Symbols - Signature}

The use of the signature was very commonplace in the Ottoman period and alongside the signee's name appeared words of benevolence and mercy. The signature placed at the end of the document was one of a simple nature comprising of only a few components. Certification wording was variable depending on the type of document in question (İpşirli 1988: 191).

Unique Symbols - Seal

The seals used on correspondence such as petitions and letters in the Ottoman State were used for the purpose of verifying and certifying the document in question. Seals can be considered in three categories; personal seals, official seals and pious foundation seals (Kütükoğlu 2013: 84). In order to ensure financial regulation in pious foundations or to hinder its misuse, the seal comprised of more than one part. Each part was entrusted to an official and the transaction could not be carried out unless all the officials possessing a part came together. Again, with the aim of preventing fraudery, the seals Keeper of Seals obtained the right to use were published in registers (Kütükoğlu 2006: 530-531).

Seals belonged to the post, organisation or individual. Individual seals comprised of name, father name and epithet as well as notability (Sertoğlu 1988: 63). In the Ottoman state generally speaking most of the population be it members of the public or officials possessed a seal.

\section{Unique Symbols - Letterhead}

The letterhead makes an appearance in the Ottoman state after the Tanzimat period. The name of each state department appeared as a letterhead on printedpaper and the use of the letterhead can be regarded as the adoption of the modern filing system in the Ottoman state (Ortayl1 1988: 167- 168).

\section{Unique Symbols - Watermark}

A watermark is the general name given to figures, symbols, markings or script which are visible upon the paper being held up to the light. Such a practice is not seen on paper produced in the East. This feature of lines found in the moulds of Western paper is the most prominent one that distinguishes it from the paper of the East (Somer 2014: 244). 
Caused by a variation in the thread and apparent when held to the light, watermarks, carrying the meaning of paper design (Pearce-Moses 2005: 406), can be seen from time to time in Ottoman records.

\section{Unique Symbols - Ornamentation}

Tezhip (Ornamentation) has the meaning of gliding. At the core of the art of ornamentation (tezyinî) lies a pattern comprising of motifs. The motifs used in ornamentation, in comparison to other decorative arts, are less elaborate and smaller in size (Birol 2012: 61). For example, the Imperial Council official documents, such as decrees, patents and appointments, which had to be similar in nature, bore a Sultanic cipher at the top of the text with adornment surrounding the cipher.

\section{References}

Acar MŞ (1999). Türk Hat Sanatı [Turkish Calligraphy Art]. İstanbul: Antik A.Ş.

Aktaş N, Kahraman S (1994) Bulgaristan'daki Osmanlı Evrakı [Ottoman Documents in Bulgaria]. Ankara: T.C. Başbakanlık Devlet Arşivleri Genel Müdürlüğü Osmanlı Arşivi Daire Başkanlığı.

Andros Island Library. Retrieved from http://bit.ly/2iSSXcK. [Accsesed 01 June 2017].

Baca M, Harpring P (2014) Categories for the Description of Works of Art: Describe and catalogue works of art, architecture, and cultural heritage (CDWA). Los Angles: Paul Getty Trust \& College Art Association, ed. Murtha Baca and Patricia Harpring.

Binark İ (1992) Başbakanlık Osmanlı Arşivi Tasnif Talimatnamesi [Ottoman Archives Classification Instruction]. Ankara: T.C. Başbakanlık Devlet Arşivleri Genel Müdürlüğü.

Birol İA (2012) Tezhip [Ornamentation]. Türkiye Diyanet Vakfi İslam Ansiklopedisi 31: 61-62.

Carter TM, Levine-Clark M (2013) ALA Glossary of Library and Information Science. Chicago: An Imprint of the American Library Association.

Derman MU (2006) Mürekkep [Ink]. Türkiye Diyanet Vakfi Íslam Ansiklopedisi 32: 46-47.

English National Archive. Retrieved from http://bit.ly/1rCGd3S. [Accessed 01 June 2017]

Erdoğdu AT (2014) Fransız Arşivlerinin Türkiye Tarihindeki Yeri ve Önemi [Place and Importance of French Archives in Turkey]. Avrupa Arşivleri'nde Osmanl Imparatorluğu, 63-85. Ankara: Vekam Yayınları.

Findley CV (1997). Hariciye Nezareti [Ministry of Foreing Affairs]. Türkiye Diyanet Vakfi İslam Ansiklopedisi 26: 178-180.

Gallica. Retrieved from http://bit.ly/2AcAKy9. [Accessed 01 June 2017].

Girgin K (2004) Osmanlı ve Cumhuriyet Dönemleri Hariciye Tarihimiz (Dışişleri ve Protokol) [Our History of Foreing Affairs in Ottoman and Republican Period (Foreing Affairs and Protocol)]. Ankara: Okumuş Adam Yayıncıllk.

Gökbilgin MT (1992) Osmanl Paleografya ve Diplomatik İlmi [Ottoman Paleography and Diplomatic Science]. İstanbul: Enderun Kitabevi.

Greek State Archives. Retrieved from http://bit.ly/2n6xoKm. [Accessed 01 June 2017]. 
İnalcık H (2017) Osmanlı ve Avrupa Osmanlı Devleti'nin Avrupa Tarihindeki Yeri [The Ottoman Empire and Europe: The Ottoman Empire and Its Place in European History]. İstanbul: Kronik.

İnalcık H (2014) Arşiv Belgeleri Işı̆̆ında Osmanlı ve Avrupa [The Ottoman Empire and Europe in The Light of Archival Documents]. Avrupa Arşivleri'nde Osmanl Imparatorluğu, 171-174. Ankara: Vekam Yayınlar1.

İpşirli M (1988) İlmiye Mensuplarının İmza ve Tasdik Formülleri [Signature and Certification Formulas of Ilmiye Members]. Tarih Boyunca Paleografa ve Diplomatik Semineri 30 Nisan-2 Mayls Bildiriler, 178-191. İstanbul: Edebiyat Fakültesi Tarih Araştırma Merkezi.

Kandur H (2006) Elektronik Belge Yönetimi Sistem Kriterleri Referans Modeli (V.2.0) [Electronic Document Management System Criteria Reference Model (V.2.0)]. Ankara: Devlet Arşivleri Genel Müdürlügü.

Köksal Y, Polatel M (2014) Sunuş: Avrupa Arşivlerinin Osmanlı Çalışmaları için Önemi [Introduction: The Importance of European Archives for Ottoman Studies]. Avrupa Arşivlerinde Osmanlı İmparatorluğu,5-14. Ankara: Vekam Yayınları.

Kurat AN (1949) İngiliz Devlet Arşivinde ve Kütüphanelerinde Türkiye Tarihine Ait Bazı Malzemeye Dair [On Some Materials of Turkish History in British State Archives and Libraries]. Ankara Üniversitesi Dil ve Tarih-Coğrafya Fakültesi Dergisi 7(1): 1-18.

Kütükoğlu M (1994) Diplomatik [Diplomatic]. Türkiye Diyanet Vakfi İslam Ansiklopedisi 9: 64-366.

Kütükoğlu M (1998) Tarih Araştırmalarında Usul [Methodology in History Research]. İstanbul: Kubbealtı Neşriyat1.

Kütükoğlu M (2006) Mühür [Seal]. Türkiye Diyanet Vakfi İslam Ansiklopedisi 31: 530-531.

Kütükoğlu M (2007) Paleografya [Paleography]. Türkiye Diyanet Vakfi İslam Ansiklopedisi 34: 153-154.

Kütükoğlu M (2013) Osmanlı belgelerinin Dili (Diplomatik) [Spesificatios of Ottoman Documents (Diplomatic)]. Ankara: Türk Tarih Kurumu.

Miscellanea documenti turchi [Various Turkish documents]. Retrieved from http://bit. ly/2jspyp4. [Accessed 01 June 2017].

Pearce-Moses R (2005) A Glossary of Archival and Records Terminology. Chicago: The Society of Americak Archivists.

Pedani MP (1994) I Documenti Turchi dell Archivio di Stato di Venezia [The Turkish Documents of the State Archives of Venice]. Rome: Ministero Per I Beni Culturali E Ambientali.

Pedani MP (2010) Inventory of the Lettere e Scritture Turchesche in the Venetian State Archives. Boston: Brill.

Ortaylı İ (1988) Osmanlı Kançılaryasında Reform: Tanzimat Devri Osmanlı Diplamatikasının Bazı Yönleri [Reform in the Ottoman Chancellery: Some Aspects of Ottoman Diplomatic]. Tarih Boyunca Paleografa ve Diplomatik Semineri 30 Nisan-2 Mayıs Bildiriler, 153-168. İstanbul: Edebiyat Fakültesi Tarih Araştırma Merkezi.

Reychman J, Zajaczkowski A (1993) Osmanl1 - Türk Diplomatikası El Kitab1 [OttomanTurkish Diplomatic Handbook]. İstanbul: T.C. Başbakanlık Devlet Arşivleri Genel Müdürlüğü.

Sertoğlu M (1988) Osmanlı Diplomatiği Bakımından Başbakanlık Osmanlı Arşivlerinde bulunan Belgelerin İlmî ve Hukukî Değerleri Hakkında Düşünceler [Thoughts on the Scientific and Legal Values of Documents in the Ottoman Archives of the Prime Ministry in Terms of Ottoman Diplomatic]. Tarih Boyunca Paleografa ve 
Diplomatik Semineri 30 Nisan-2 Mayls Bildiriler, 59-70. İstanbul: Edebiyat Fakültesi Tarih Araştırma Merkezi.

Somer ŞN (2014) Reasons Behind The Survival of Ottoman Archival Documents Until Today: Paper, Ink, and Binding Features. Muhasebe ve Finans Tarihi Araştırmaları Dergisi, 238-262.

Database of Ottoman Documents in Crill i Methodius Library. Retrieved from http:// bit.ly/2Aa7I4N. [Accessed 01 June 2017].

Torunlar M, Çelik E (1993) Bulgaistan'a Satılan Evrak ve Cumhuriyet Dönemi Arşiv Çalısmaları [Documents Sold to Bulgaria and Archival Studies in Repuclican Period]. Ankara: T.C. Başbakanlık Devlet Arşivleri Genel Müdürlüğü Cumhuriyet Arşivi Daire Başkanlığı.

Turgut AY (2009) Tuğra Süslemeleri [Ornament of Sultanic Cipher]. İstanbul Büyükşehir Belediyesi Sanat ve Meslek Eğitimi Kursları El Sanatları Dergisi (ISMEK), 80-85.

Ünver, M. (2014) Son Dönem Osmanlı Tarih Araştırmaları Açısndan İngiliz Milli Arşivi ve Arşiv Belgelerinin Önemi [The Importance of the British National Archives and Archive Documents in Terms of Recent Late Ottoman History Surveys]. Avrupa Arşivleri'nde Osmanlı İmparatorluğu, 105-119. Ankara: Vekam Yayınları. 
